\title{
ВСЕУКРАЇНСЬКА НАУКОВО-ПРАКТИЧНА
}

\section{ІНТЕРНЕТ-КОНФЕРЕНЦІЯ «ОСВІТНІЙ ПРОЦЕС У ЗАКЛАДАХ ДОШКІЛЬНОЇ ОСВІТИ: СУТНІСТЬ ТА ІННОВАЦИЙНЙ ПОТЕНЦІАЛ»}

https://doi.org/10.37472/2707-305X-2021-3-1-11-3

РЕЙПОЛЬСЬКА

Ольга Дмитрівна

доктор педагогічних наук, дочент, завідувач лабораторії дошкільної освіти та виховання Інституту проблем виховання Національної академії педагогічних наук України, м. Київ, Україна

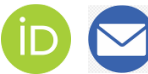

\section{РАГОЗІНА}

\section{Вікторія Валентинівна}

кандидат педагогічних наук, старший науковий співробітник, провідний науковий співробітник лабораторії дошкільної освіти та виховання Інституту проблем виховання Національної академії педагогічних наук України, м. Київ, Україна

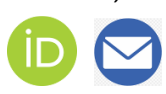

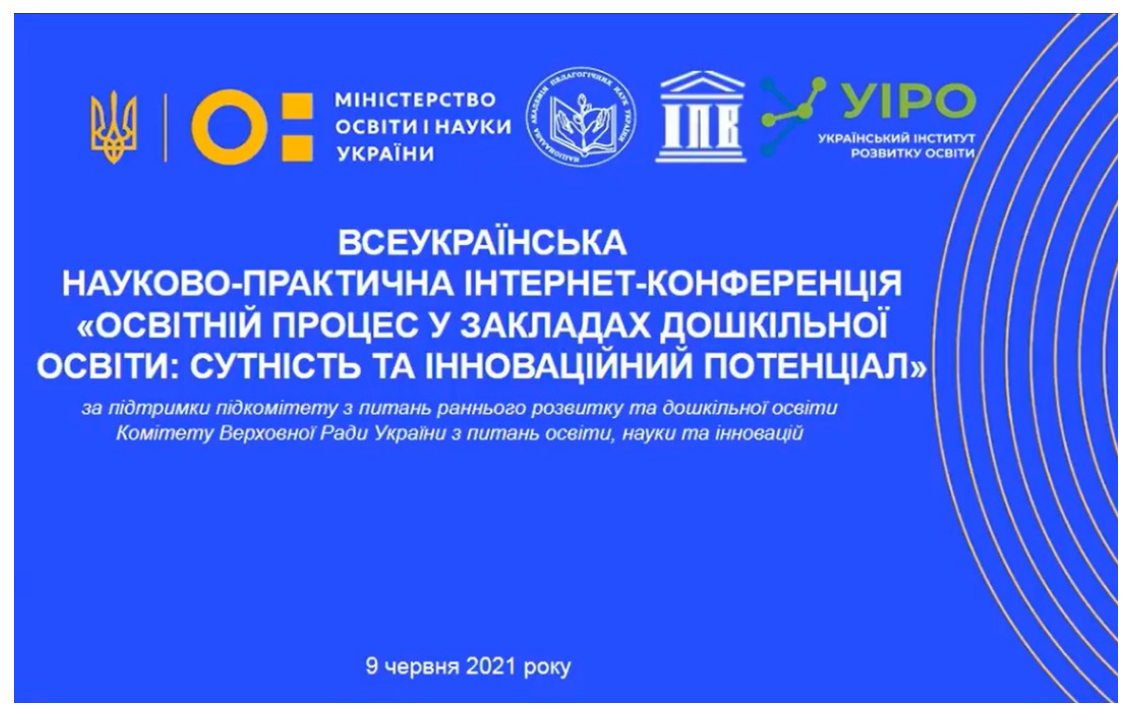

Анотація. У статmі висвітлено результати роботи Всеукраїнської науково-практичної інтернет-конференції «Освітній процес у закладах дошкільної освіти: сутність та інноваційний потенціал», що відбулася 9 червня 2021 р. Метою конференції було обговорення актуальних проблем розроблення та впровадження інноваційних технологій розвитку, виховання і навчання дітей в освітньому прочесі закладів дошкільної освіти України, презентування новітніх практик працівників закладів дошкільної освіти. Організаторами конференції виступили Міністерство освіти і науки України, Національна академія педагогічних наук України (Відділення загальної педагогіки та фрілософії освіти), Інститут проблем виховання Національної академії педагогічних наук України, Державна установа "Український інститут розвитку освіти». Захід всеукраїнського рівня проводився за підтримки підкомітету з питань раннього розвитку та дошкільної освіти Комітету Верховноі Ради України з питань освіти, науки та інновацій.

Ключові слова: дошкільна освіта; заклади дошкільної освіти; ранній дошкільний вік; дошкільний вік; інтерактивні технології; сучасне освітнє середовище.

9 червня 2021 р. відбулася Всеукраїнська науково-практична інтернет-конференція "Освітній процес у закладах дошкільної освіти: сутність та інноваційний потенціал», яка об'єднала понад 1,6 тис. учасників. Зокрема, у заході взяли участь представники Міністерства освіти і науки України, провідні вчені Національної академії педагогічних наук України, викладачі закладів вищої освіти та фахівці дошкільної галузі 3 понад 18 областей (Вінницької, Дніпропетровської, Донецької, Запорізької, Житомир- 
ської, Івано-Франківської, Київської, Кіровоградської, Миколаївської, Одеської, Полтавської, Рівненської, Сумської, Тернопільської, Харківської, Херсонської, Хмельницької, Черкаської).

у вітальному слові президент Національної академії педагогічних наук України, доктор філософських наук, професор, дійсний член (академік) НАН України і НАПН України В.Г. Кремень наголосив на тому, що ранній та дошкільний період дитинства позначається на

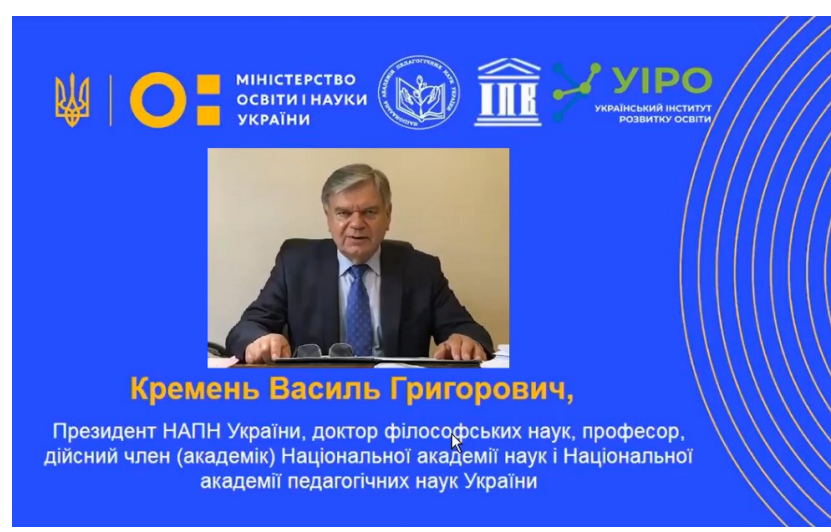

життєдіяльності людини впродовж усього її життя. Тому важливим є усвідомлення суспільством значущості розвитку особистості дитини та місії вихователів у цьому процесі. Водночас сучасна дошкільна освіта потребує вирішення ключових проблем: забезпечення доступу до якісної дошкільної освіти на базі державних, комунальних і приватних установ, необхідності використання для цього всіх можливостей закладів дошкільної освіти, а також належного цінування праці вихователів, діяльність яких спрямовано на благо дитини та сприяння розвитку ії талантів і самореалізації.

В.Г. Кремень підкреслив, що синергія зусиль Національної академії педагогічних наук України з Міністерством освіти і науки України та підкомітетом з питань раннього розвитку та дошкільної освіти Комітету Верховної Ради України з питань освіти, науки та інновацій сприяє вирішенню актуальних проблем дошкільної галузі.

Вітання учасникам і гостям конференції виголосив голова підкомітету з питань раннього розвитку та дошкільної освіти Комітету Верховної Ради України з питань освіти, науки та інновацій B.A. Воронов, який відзначив позитивні зрушення у законодавчій базі дошкільної освіти і висловив вдячність науковцям і практикам дошкільної ланки освіти за нові ініціативи, що сприяють розвитку дошкільної галузі.

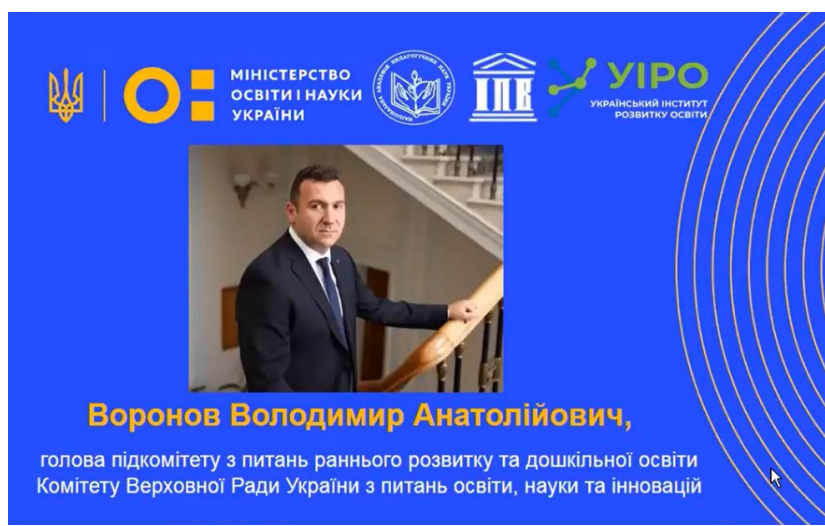

До присутніх звернувся директор Державної установи «Український інститут розвитку освіти» B.А. Карандій. Серед завдань діяльності Українського інституту розвитку освіти (УІРО) як агенції для впровадження освітніх реформ В.А. Карандій відмітив сприяння розбудові дошкільної галузі і впровадженню освітніх інновацій у сучасну систему дошкільної освіти України. 3 огляду на це пріоритетними напрямами діяльності Українського інституту розвитку освіти $€$ участь у процесі оновлення Базового компоненту дошкільної освіти, розробленні професійного стандарту вихователя, проведенні дослідження якості освіти у закладах дошкільної освіти за міжнародною методикою ECERS-3.

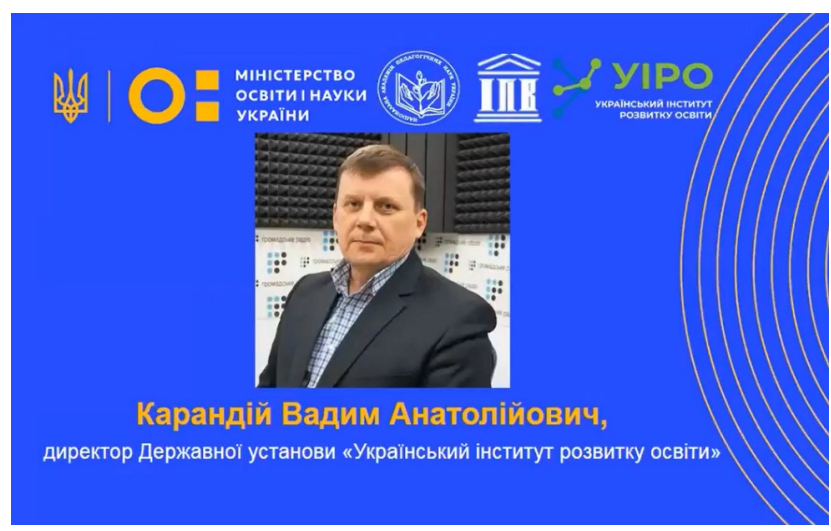

Директор Інституту проблем виховання НАПН України, доктор психологічних наук, професор, дійсний член (академік) НАПН України І.Д. Бех у своєму виступі генералізував концептуальні проблеми дошкільної освіти та раннього розвитку дитини. Вчений відмітив зміни у дошкільній освіті сьогодення, зокрема оновлення ії̈ змісту, форм і методів, та наголосив на необхідності пошуку шляхів для забезпечення вікової зрілості дитинидошкільника.

На основі аналізу доробку вітчизняних і зарубіжних учених І.Д. Бех запропонував орієнтири, що сприяють оптимізації процесу виховання дитини дошкільного віку: 


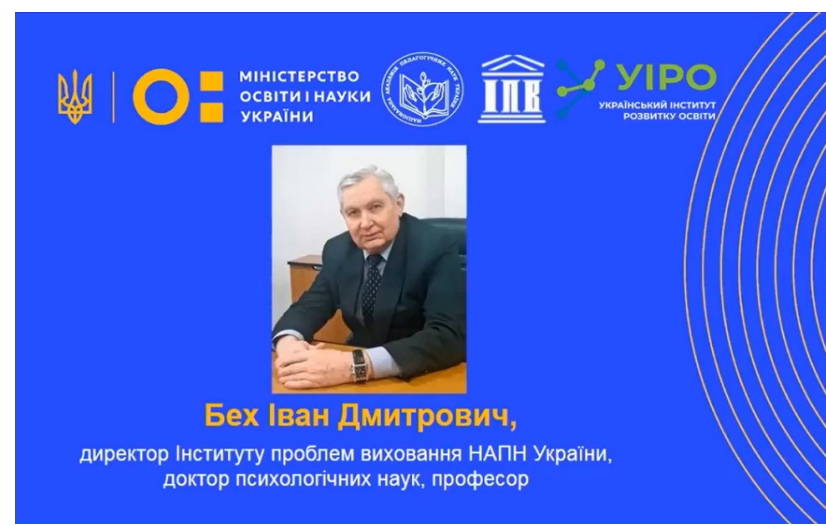

1) оптимальна формула виховання дитинидошкільника передбачає таку батьківську модель поведінки, яка пропонується дитині для наслідування у формі її вчинків, що схвалюються батьками;

2) успішність виховання дитини-дошкільника слід пов'язувати із запобіганням формування у неї досвіду моральної некомпетентності;

3) однією з головних цілей, яку має ставити суспільство перед зростаючою особистістю починаючи з дошкільного віку, повинно бути виховання широкої соціальної місії - «бути необхідним людям» у ролі помічника, порадника, організатора та вправлятися у цих ролях щоденно; саме у таких життєвих діяннях відбувається соціальний розвиток зростаючої особистості, який у подальшому передбачає професійну самодостатність;

4) у сфері емоційного розвитку дітидошкільники мають опановувати нові, відповідні до віку, емоційні способи реагування на певні стимули. Нейтралізувати емоційний опір чи негативізм дитини доцільно шляхом самоусвідомлення нею своїх здібностей і того, що є прийнятним для інших людей;

5) віково-ціннісний розвиток дитини-дошкільника забезпечується якомога більш раннім переходом від внутрішньої позиції «Хочу дайте» до «Хочу - створюю», які слід гармонізувати. За другої позиції дитина виростає творцем, з неї розпочинається тривалий шлях до набуття дитиною свободи як вищої цінності. Означена позиція у навчально-виховному плані має забезпечуватися узгодженими в часі різними видами дитячої предметно-перетворювальної діяльності, спільно мотивованої якраз прагненням створювати нове. Тож тільки для творення зростаюча особистість повинна вчитися, а мотив творення для неї має стати всеосяжним

Сучасна дошкільна освіта перебуває у вирі реформаційних та модернізаційних змін - це зазначила у своєму виступі C.І. Нерянова, началь- ник відділу дошкільної освіти Директорату дошкільної, шкільної, позашкільної та інклюзивної освіти Міністерства освіти і науки України. Доповідачка наголосила, що пріоритети державної політики у сфері дошкільної освіти - це насамперед забезпечення доступності та якості освіти. Під час виступу було наведено статистичні дані щодо мережі закладів дошкільної освіти різних типів і форм власності, кількості інклюзивних груп у цих закладах тощо. Відмічено, що попри позитивну динаміку, існує проблема 3 охопленням дошкільною освітою дітей різних вікових груп, обумовлена, зокрема, й пандемією, що почалася у 2020 р.

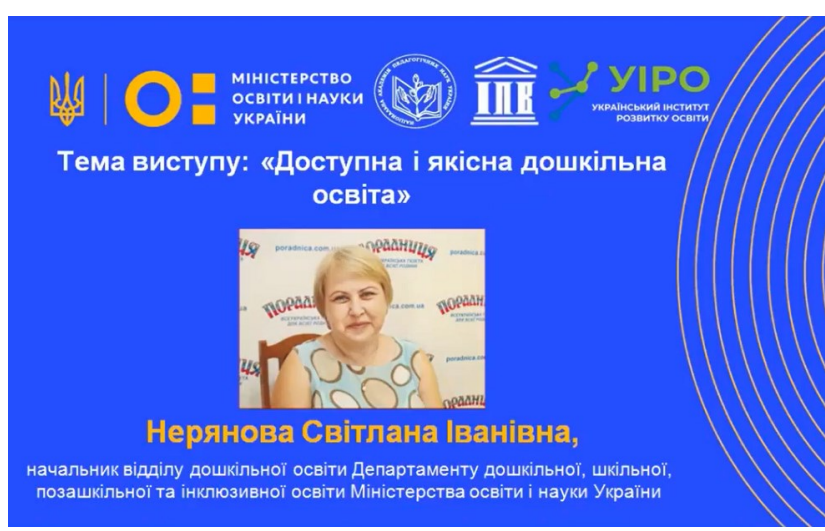

У виступі було окреслено форми здобуття дошкільної освіти, критерії якісної дошкільної освіти та кроки щодо цього, пов'язані насамперед із оновленням ії змісту - Базового компоненту дошкільної освіти і освітніх програм, серед яких 10 комплексних і 29 парціальних. Зупинилась C.І. Нерянова і на необхідності контролю за якістю дошкільної освіти, що здійснюється Державною службою якості освіти; відповідно внесено зміни до Положення про заклад дошкільної освіти.

Завідувач лабораторії психології дошкільника Інституту психології імені Г.С. Костюка НАПН України, доктор психологічних наук, професор T.О. Піроженко презентувала проєкт всеукраїнського рівня «Впевнений старт» як цілісну педагогічну систему, що чотири роки поспіль впроваджується у закладах дошкільної освіти України. Програмно-методичний комплекс «Впевнений старт» $€$ результатом творчої співпраці вчених Інституту психології імені Г. С. Костюка НАПН України, Інституту проблем виховання НАПН України, Української Академії дитинства. Проєкт охоплює учасників освітнього процесу (дітейдошкільників, вихователів закладів дошкільної освіти і батьків) та успішно реалізується з дітьми 


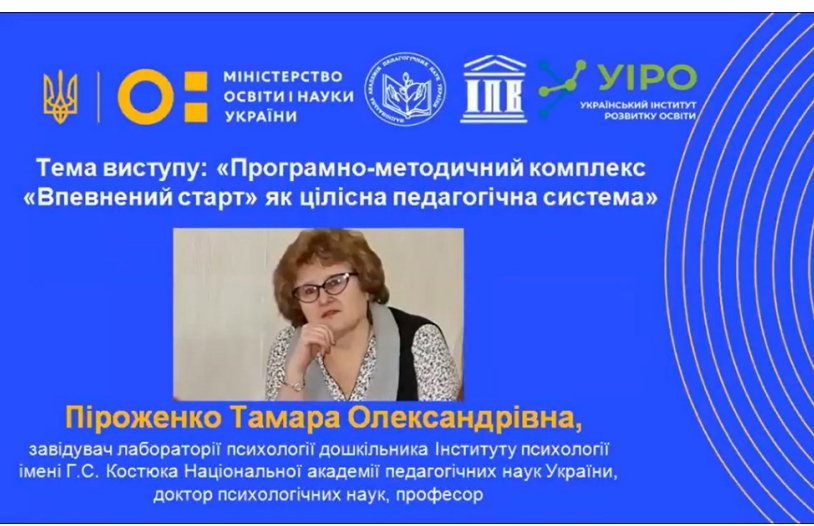

молодшого, середнього і старшого дошкільного віку у закладах дошкільної освіти різних типів і форм власності всіх регіонів України. Інноваційний проєкт «Впевнений старт» ґрунтується на сучасних методологічних підходах і принципах, відповідає сучасним світовим освітнім тенденціям й водночас враховує і зберігає національні традиції.

Актуальною $€$ проблема оцінювання якості освітнього процесу в закладах дошкільної освіти, яку підняла у своєму виступі начальник відділу дошкільної та початкової освіти Державної установи «Український інститут розвитку освіти», кандидат педагогічних наук, доцент О.Г. Косенчук. Доповідачка висвітлила досвід дієвої співпраці вітчизняних наукових установ $з$ міжнародними організаціями - ЮНІСЕФ, Європейським центром ім. Вергеланда, підсумком якої стала реалізація ряд освітніх проєктів, зокрема і у галузі дошкільної освіти. Так, у партнерстві Державної установи «Український інститут розвитку освіти» з Командою підтримки реформ МОН України, Всеукраїнським фондом «Крок за кроком» та за підтримки ЮНІСЕФ в Україні розроблено шкалу оцінювання якості освітнього процесу в закладах дошкільної освіти України за методикою ECERS (Early Childhood Environment Rating Scale). Під час виступу розкрито особливості процедури оцінювання якості

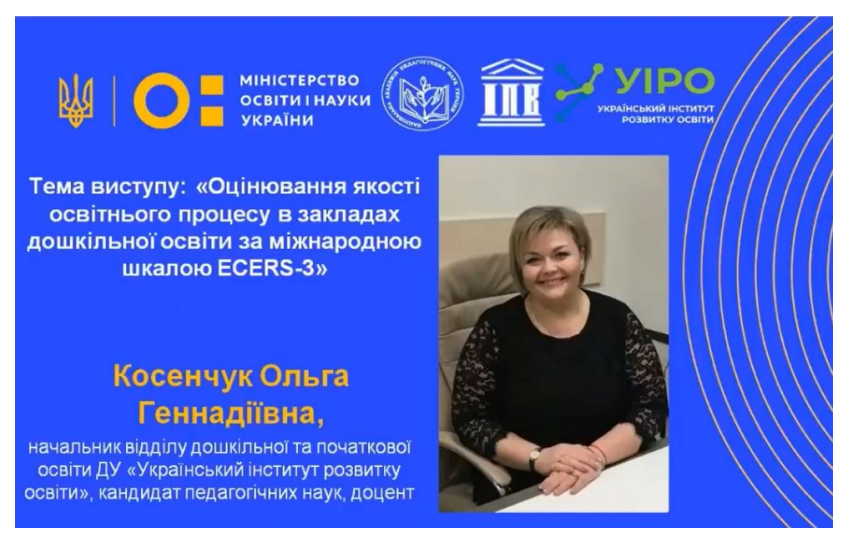

освітнього процесу в закладах дошкільної освіти України за міжнародною шкалою ECERS-3 та запропоновано учасникам конференції більш ґрунтовно ознайомитися із методикою за матеріалами, розміщеними на сайті МОН України у відповідному підрозділі.

Інноваційний підхід в освіті та догляді дітей дошкільного віку - «Mr. Leader. Education \& Care System», розроблений під керівництвом В.А. Воронова, був презентований у виступі Н. В. Піканової, наукового співробітника відділу освіти дітей з порушеннями слуху Інституту спеціальної педагогіки і психології імені Миколи Ярмаченка НАПН України, директоркою Дитячого центру «Mr. Leader».

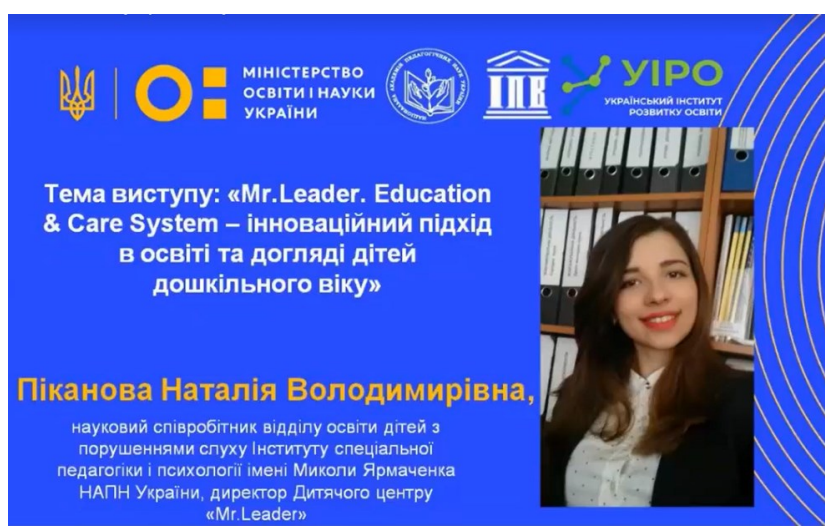

Н.В. Піканова розкрила сутність «Mr. Leader. Education \& Care System» як інноваційної системи освіти та догляду дітей, спрямованої на пробудження в них лідерських якостей, що реалізується програмно-методичним і дидактичним забезпеченням. Так, «Mr. Leader day» - це програма роботи вихователя з однією дитиною чи групою дітей на кожний день у певній тематиці, зокрема, як корисно провести час, поступово формуючи ті чи інші лідерські якості. Плани-конспекти для цього представлено у форматі візуальних і зручних у роботі карт. Цікаві й ілюстративні картки у комплекті «Mr. Leader cards» призначені для показу дітям. «Mr. Leader posters» - це спеціально розроблені тематичні плакати, які можна використати під час проведення різноманітних видів діяльності з дітьми. «Mr. Leader games» включає різноманіття ігор (лото, пазли, наліпки). Система також передбачає перспективу навчання дітей основ фінансової грамотності, для цього розроблено навіть спеціальну валюту (лідери), щоб діти змалечку вправлялися у фінансових відносинах. Для зручності батьків розроблено електронну програму, в якій їм зручно відслідковувати розвиток своїх дітей. 
Унікальним $є$ самовчитель лідерства, де прописано й проілюстровано основні правила лідера. Отже, розроблена система, реалізована в друкованій та електронній продукції із сучасним і цікавим дизайном, слугує меті допомагати вихователям і батькам у реалізації означеного підходу - формуванні справжнього лідера.

Змістовну доповідь, присвячену векторам супроводу мистецької діяльності в освітньому процесі закладу дошкільної освіти, виголосила О.А. Половіна, доцент кафедри дошкільної освіти Київського університету імені Бориса Грінченка, кандидат педагогічних наук, доцент. Дослідниця

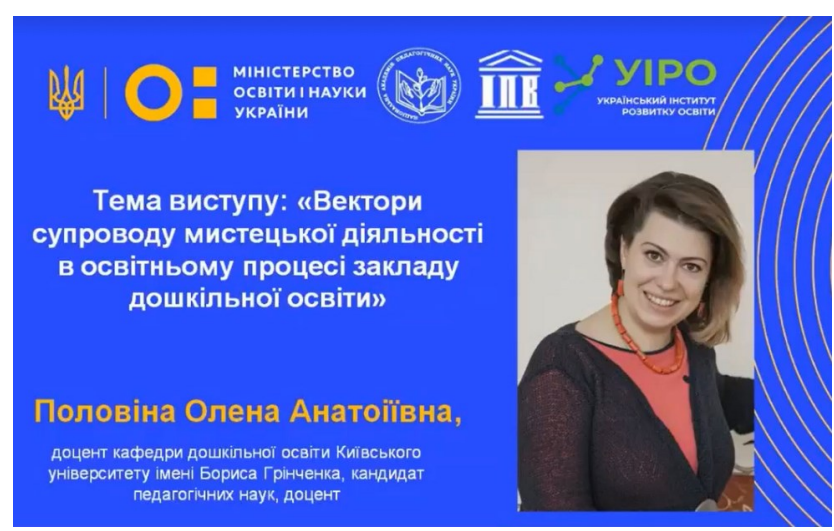

виокремила та обґрунтувала такі вектори: автономність вихователя у реалізації завдань освітнього напряму «Дитина у світі мистецтва»; зміна орієнтирів: від відтворення художнього образу - до створення художнього образу; створення простору для мистецької діяльності дитини; доцільність методичного інструментарію; наявність рефлексійного середовища; відчуття дитиною значущості і задоволення від своєї художньої діяльності; критичне мислення вихователя в організації художньої діяльності дитини.

Цінними для практиків стали наведені О.А. Половіною технології, що уможливлюють реалізацію зазначених векторів, серед яких і авторська технологія дитячого образотворення - без наслідування і зразків вихователя.

Інноваційний потенціал ігротехнологій у формуванні логіко-математичної компетентності дошкільників у світлі положень Базового компоненту дошкільної освіти (2021р.) розкрила О.Г. Брежнєва, доктор педагогічних наук, професор, завідувач кафедри дошкільної освіти Маріупольського державного університету. Дослідниця зазначила, що функція гри не повною мірою реалізовується у математичному розвитку дошкільників; з огляду на це було розглянуто

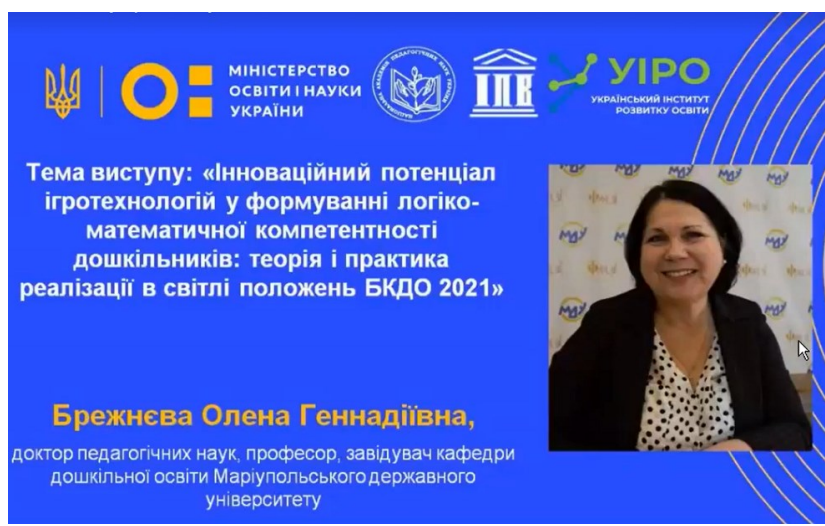

різноманіття ігротехнологій, розкрито їх сутність та наведено приклади й методичні поради щодо застосування ігротехнологій у дошкільній практиці, що особливо цінується вихователями закладів дошкільної освіти.

Продовжила тему реалізації інноваційних технологій у освітньому процесі закладів дошкільної освіти Н.В.Гавриш, головний науковий співробітник лабораторії дошкільної освіти і виховання Інституту проблем виховання НАПН України, доктор педагогічних наук, професор. Вчена акцентувала увагу учасників конференції на технології фокусного навчання як інструменті якісної освіти дошкільників та деталізувала технологічний процес на прикладах ознайомлення дітей дошкільного віку 3 літературними творами.

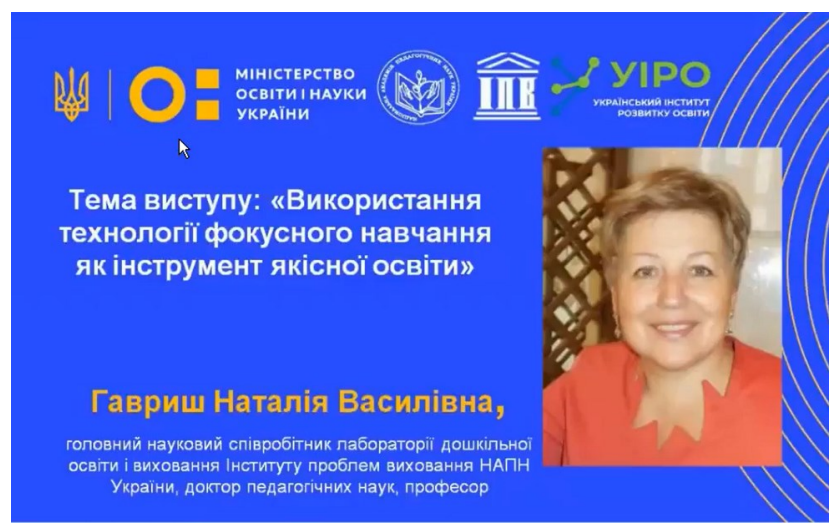

Інноваційний потенціал імерсійного заняття 3 дітьми дошкільного віку висвітлила К.Л. Крутій, професор кафедри дошкільної освіти Вінницького державного педагогічного університету імені Михайла Коцюбинського, доктор педагогічних наук, професор. Доповідачка ґрунтовно розкрила сутність поняття «подієвість» як феномену Дитинства і наголосила на можливості події у забезпеченні іï учасникам «психологічного прориву», виходу за межі їхнього наявного життєвого досвіду. Вченою розкрито причини переходу до подієвості та конкретизовано 


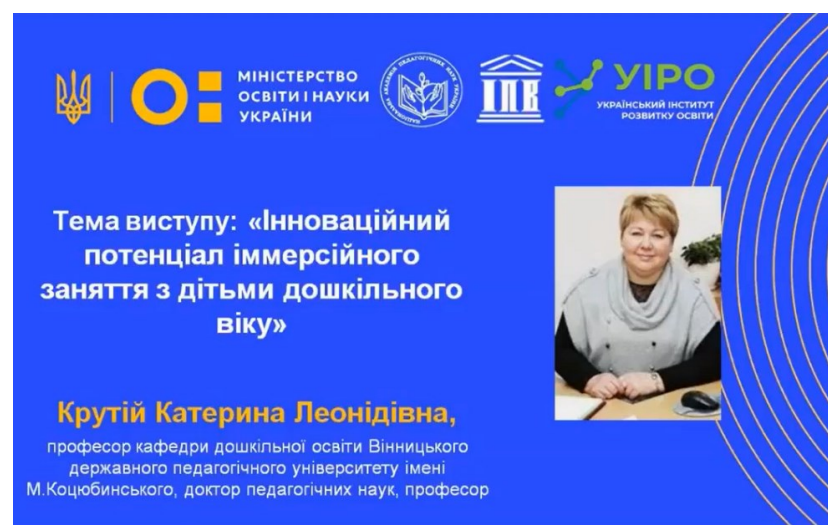

формати імерсійного заняття з дошкільниками й особливості їх проведення.

Після завершення пленарної частини конференції присутні мали можливість ознайомитися $з$ прогресивними практиками з актуальних завдань дошкільної освіти шляхом участі у майстер-класах від провідних фахівців дошкільної галузі.

У ході майстер-класу «Впровадження курсу «Дошкільнятам - освіта для сталого розвитку» його модератори - О.А. Орлова (викладач кафедри дошкільної освіти Житомирського інституту післядипломної педагогічної освіти, кандидат педагогічних наук, доцент) і Т.Ю. Сімайкіна (методист закладу дошкільної освіти № 57 м. Житомира) ознайомили колег 3 кращим досвідом житомирських закладів дошкільної освіти у впровадженні положень сталого розвитку та його результатами. Однією з дієвих форм роботи садочків виявилася співпраця 3 громадою у формуванні екологічної компетентності дітей, що досягалося шляхом участі дітей у флешмобах, фестивалях, акціях («День Землі», «День води», «День світла» та ін.) та у різновидах діяльності, де вони створювали корисні речі 3 покидькових матеріалів, обговорювали в групах важливі питання збереження довкілля - водночас діти вчилися бути дорослими, брати відповідальність за свою поведінку і стимулювати дорослих бути свідомими. Модератори показали

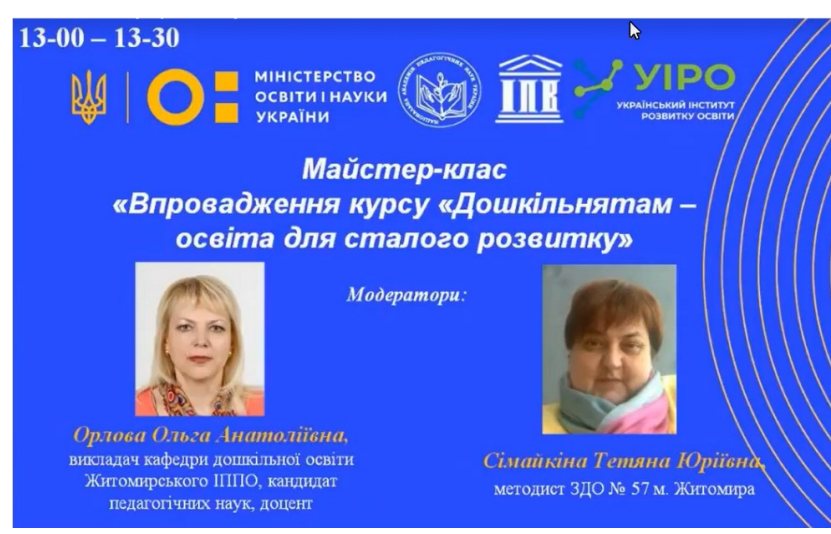

присутнім, як ці заходи можна переформатувати в умовах пандемії.

Технологію сприймання художніх творів дітьми раннього віку презентувала В.В. Рагозіна (провідний науковий співробітник лабораторії дошкільної освіти і виховання Інституту проблем виховання НАПН України, кандидат педагогічних наук, старший науковий співробітник). Наголошено на інноваційності технології, що враховує специфіку художнього розвитку дітей раннього віку, розкрито компоненти авторської технології

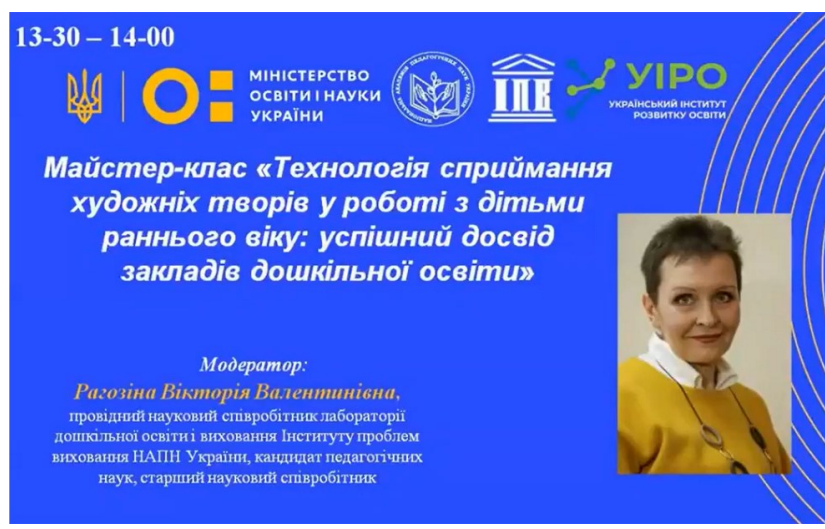

та успішний досвід ії реалізації на базі закладів дошкільної освіти м. Суми (№ 13 «Купава», № 28 «Ювілейний», № 26 «Ласкавушка») і м. Ромни Сумської області (№ 4 «Малятко», № 9 «Фіалка»). Окрасою виступу стали продемонстровані відеофрагменти занять вихователів вищеозначених закладів, що засвідчили дієвість технології та успішність ї̈ опанування вихователями в новій формі навчання - професійному майстермайнді.

Майстер-клас «Впровадження програмнометодичного комплексу «Впевнений старт» провела модератор О.Ю. Хартман (кандидат психологічних наук, старший науковий співробітник, старший науковий співробітник лабораторії розвитку дошкільника Інституту психології імені Г.С. Костюка НАПН України). Доповідачка ґрунтов-

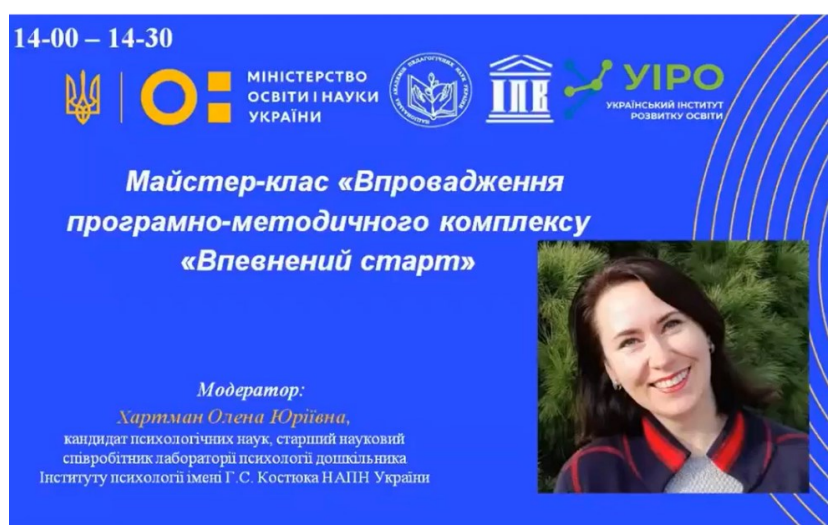


но роз'яснила зміст і процедуру впровадження програмно-методичного комплексу «Впевнений старт» у освітньому процесі закладів дошкільної освіти: змістові та процесуальні особливості застосування, психолого-педагогічні умови реалізації програмових завдань, основні форми, методи й засоби організації освітньої діяльності, зокрема висвітлила рівні впровадження (репродуктивний і творчий) програмно-методичного комплексу.

Цікаві інновації освітньої роботи в розвивальному середовищі закладу дошкільної освіти висвітлили модератори О.К. Безсонова (директор Комунального дошкільного навчального закладу (ясла-садок) № 67 «Сонячний» комбінованого типу Краматорської міської ради, кандидат педагогічних наук) і О.Д. Рейпольська (завідувач лабораторії дошкільної освіти і виховання Інституту проблем виховання НАПН України, кандидат педагогічних наук, доцент). Модератори

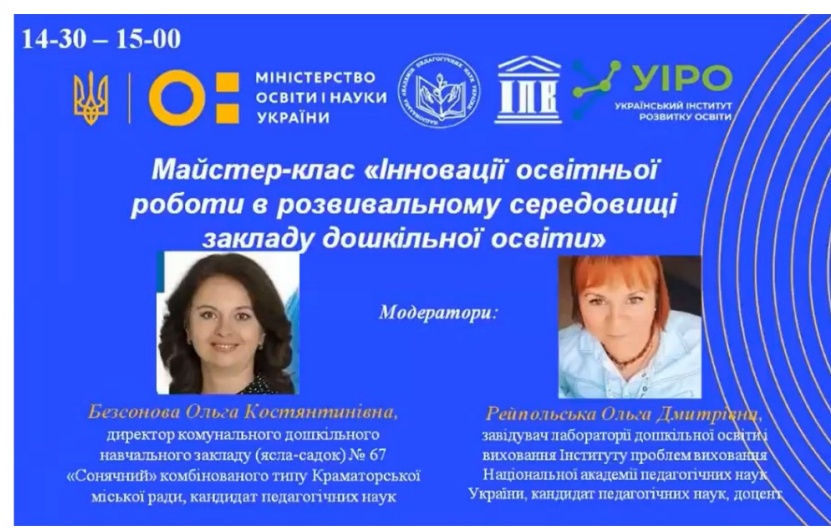

пояснили принципи побудови освітнього розвивального середовища у закладі дошкільної освіти (фокусний формат, забезпечення зони комфорту дитини, перевага конструкцій, створених власними силами учасників освітньої взаємодії (батьків, вихователів), над готовими іграми та іграшками), принципи планування. Модератори навели приклади різноманітного інструментарію у роботі з дітьми, а також адресували глядачів на гуглдиск із авторськими напрацюваннями.

Заключною частиною конференції, що відбулася у форматі інтерактивного обміну думками і враженнями учасників зібрання, став «Відкритий мікрофон». Упродовж реєстрації на конференцію учасники мали змогу задати свої запитання. Надійшло понад 1500 запитань, що охоплюють різні аспекти проблеми реалізації освітнього процесу у закладах дошкільної освіти. Така надзвичайна активність практиків засвідчила їх гостру потребу дійти до «суті питання» - розібратися у реформаційних змінах галузі та отримати

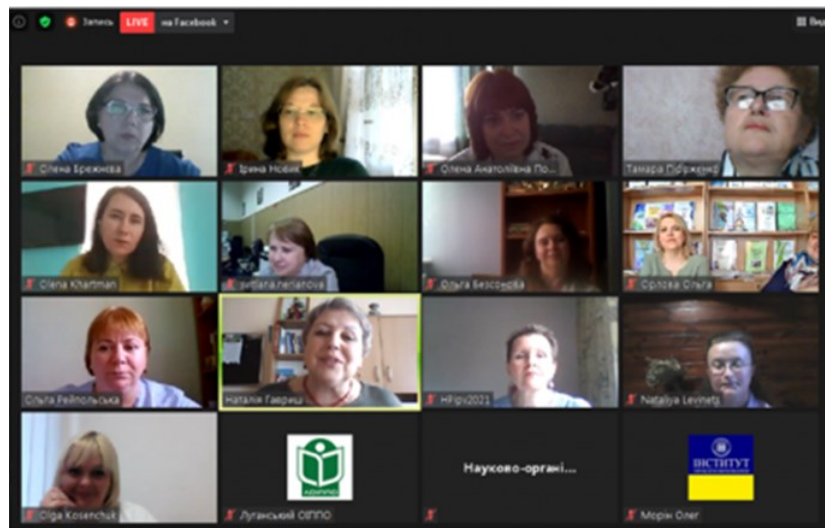

професійну консультацію від найкращих ї̈ фахівців. Запитання практиків було проаналізовано та поєднано у блоки; на них змістовно відповіли спікери конференції; відповіді на інші запитання буде представлено на сторінках найближчих номерів українського освітянського видання «Методична скарбничка вихователя».

Всеукраїнська науково-практична конференція «Освітній процес у закладах дошкільної освіти: сутність та інноваційний потенціал» успішно відбулась як важлива подія у дошкіллі. Захід засвідчив високий інтерес до проблем дошкільної освіти фахівців - представників усіх областей України - науковців, викладачів закладів вищої і післядипломної освіти, студентів, вихователів закладів дошкільної освіти різних типів і форм власності. Про готовність колег до спільного вирішення важливих проблем дошкільної освіти на запити українського суспільства засвідчила участь присутніх у обговоренні важливих і дискусійних питань розвитку дошкільної галузі, що можуть бути вирішеними тільки за умов співпраці Міністерства освіти і науки України, державних установ, провідних учених і практиків.

Плідна наукова дискусія учасників Всеукраїнської науково-практичної інтернет конференції «Освітній процес у закладах дошкільної освіти: сутність та інноваційний потенціал» сприяла не лише глибшому розумінню проблематики дошкільної освіти, а й спільному пошуку дієвих шляхів вирішення актуальних проблем дошкільної освіти.

\section{СПИСОК ВИКОРИСТАНИХ ДЖЕРЕЛ}

Воронов, В.А., Гавриш, Н.В., Канішевська, Л.В., Піроженко, Т.О., Рейпольська, О.Д., \& Сисоєва, С.О. (Укл.). (2020). Концепиія освіти дітей раннього та дошкільного віку. Національна академія педагогічних наук України. Київ. ФОП Ференець В.Б. https:// bit.ly/2E3xuLJ

Канішевська, Л.В. (2021). Забезпечення якості освіти дітей раннього та дошкільного віку у приватному 
секторі: наука і практика. Вісник Національної академії педагогічних наук України, 3(1). https:// doi.org/10.37472/2707-305X-2021-3-1-5-5

Малиношевський, Р.В., \& Рейпольська, О.Д. (2020). Методологічний семінар Національної академії педагогічних наук України «Дошкільна освіта в контексті ідей Нової української школи». Вісник Національної академії педагогічних наук України, 2(2). https://doi.org/10.37472/2707-305X-2020-2-2-3-3

Міністерство освіти і науки України. (2021, 12 січня). Про затвердження Базового компонента дошкільної освіти (Державного стандарту дошкільної освіти) нова редакція (33). https:// bit.ly/39UTWUn

Міністерство освіти і науки України. (2021, 9 червня). Всеукраїнська науково-практична інтернетконфреренція "Освітній процес у закладах дошкільної освіти: сутність та інноваційний потенціал» [Відео]. Facebook. https://www.facebook.com/ 589347414425174/videos/817957485503354

Міністерство освіти і науки України. (2021, 10 червня). Освітній процес у закладах дошкільної освіти - відбулась Всеукраїнська науково-практична онлайн-конфреренція. https://bit.ly/2Und3BF

Національна академія педагогічних наук України. (2021, 10 червня). Освітній прочес у закладах дошкільної освіти: інновації на часі. http:// naps.gov.ua/ua/press/releases/2348/

Сисоєва, С.О., \& Рейпольська, О.Д. (2020). Концепція освіти дітей раннього та дошкільного віку: новий погляд. Вісник Начіональної академії педагогічних наук України, 2(1). https://doi.org/10.37472/2707305X-2020-2-1-2-2

Український інститут розвитку освіти. (2021, 9 червня). Освітній процес у закладах дошкільної освіти: сутність та інноваційний потенціал [Відео]. Facebook. https://www.facebook.com/112412297119173/ videos/481153026447932

Український інститут розвитку освіти. (2021, 10 червня). "Освітній процес у закладах дошкільної освіти: сутність та інноваційний потенціал»: Iнтернет-конференція. https://bit.ly/3ACi7Sz

\section{ALL-UKRAINIAN SCIENTIFIC AND PRACTICAL ONLINE CONFERENCE «EDUCATIONAL PROCESS IN PRESCHOOL EDUCATION INSTITUTIONS: THE ESSENCE AND INNOVATIVE POTENTIAL»}

\section{Olha Reipolska}

DSc in Pedagogy, Associate Professor, Head of the Preschool Education Laboratory, Institute of Problems on Education of the National Academy of Educational Sciences of Ukraine, Kyiv, Ukraine Victoriia Rahozina

PhD in Pedagogy, Senior Researcher, Leading Research Fellow of the Preschool Education Laboratory, Institute of Problems on Education of the National Academy of Educational Sciences of Ukraine, Kyiv, Ukraine

Abstract. The article highlights the results of the All-Ukrainian Scientific and Practical Online Conference "Educational Process in Preschool Education Institutions: the Essence and Innovative Potential» held on June 9, 2021. The conference aimed at discussing current issues of design and implementation of innovative technologies for children development, upbringing and training in the educational process of preschool education institutions in Ukraine, presenting the latest practices of preschool education institutions teaching staff. The conference was organized by the Ministry of Education and Science of Ukraine, National Academy of Educational Sciences of Ukraine (Division of General Pedagogy and Philosophy of Education), Institute of Problems on Education of the National Academy of Educational Sciences of Ukraine, State Institution "Ukrainian Institute for Education Development». The all-Ukrainian event was supported by the Subcommittee on Early Development and Preschool Education of the Verkhovna Rada of Ukraine Committee on Education, Science and Innovations.

Keywords: preschool education; preschool education institutions; early preschool age; preschool age; interactive technologies; modern learning environment. 